\title{
Dokonania onomastyczne profesora Witolda Mańczaka (1924-2016)
}

Profesor Witold Mańczak urodził się 12 sierpnia 1924 r. w Sosnowcu. Zmarł 12 stycznia 2016 r. w Krakowie w wieku 92 lat. Był wybitnym polskim językoznawcą, romanistą i indoeuropeistą, profesorem emerytowanym Uniwersytetu Jagiellońskiego, autorem blisko tysiąca prac naukowych, w tym dwudziestu czterech monografii, znawcą języków romańskich, ale także słowiańskich, członkiem Polskiej Akademii Umiejętności oraz Polskiej Akademii Nauk. Zajmował się w szczególności językoznawstwem ogólnym, francuskim, polskim i słowiańskim, gramatyką opisową kilku różnych języków, onomastyką, prawami rządzącymi ewolucją formalną języków.

Edukację licealną profesor Mańczak rozpoczął w okresie przedwojennym. Na czas wojny musiał ją przerwać. Maturę złożył w 1945 r. i podjął studia na Akademii Handlowej, którą ukończył w 1947 r. Studiował jednocześnie filologię romańską na Uniwersytecie Jagiellońskim. Tytuł magistra romanistyki uzyskał w 1948 r. Dwa lata później - doktora nauk humanistycznych. Stanowisko na krakowskiej uczelni otrzymał w roku 1954, początkowo jako zastępca profesora, następnie od 1957 r. jako docent, od roku 1971 - profesor nadzwyczajny, od 1972 - profesor zwyczajny. W latach 1970-1974 kierował Instytutem Filologii Romańskiej UJ. W latach 1954-1958 był sekretarzem Polskiego Towarzystwa Językoznawczego. Od 1967 do 1972 - sekretarzem Polskiego Towarzystwa Popierania Współpracy Naukowej z Francją. W latach sześćdziesiątych XX w. opracował i opublikował serię gramatyk synchronicznych i diachronicznych języków romańskich - francuskiego, włoskiego i hiszpańskiego. Do kanonu lektur językoznawczych przeszło jego $Z$ zagadnień językoznawstwa ogólnego (1970). W obszarze międzynarodowym był uznanym i często cytowanym indoeuropeistą oraz onomastą. Do końca swojej aktywności naukowej dużo uwagi poświęcał „kryterium prawdy” w językoznawstwie i innych naukach humanistycznych, które jego zdaniem nie wynika $z$ obiektywnych przesłanek i pomija w dociekaniach badawczych metody statystyczne czy matematyczne. Był autorem m.in. kontro- 
wersyjnego twierdzenia, że nieregularny rozwój fonetyczny spowodowany jest frekwencją, obok regularnego rozwoju fonetycznego i rozwoju analogicznego, które decydują o formie słowa (zob. np. Le développement phonétique des langues romanes et la fréquence, Kraków 1969, Frequenzbedingter unregelmäßiger Lautwandel in den germanischen Sprachen, Wrocław 1987).

W obszarze onomastyki wypowiadał się na temat istoty nazw własnych, obstając za ich nieprzetłumaczalnością jako jednostek językowych. Uznawał ponadto, że onimy posiadają wiele desygnatów, co dotyczyć ma choćby antroponimów w postaci imion i nazwisk. Opublikował wiele prac z zakresu etymologii, funkcjonowania i natury nazw własnych, przede wszystkim toponimów oraz antroponimów (zob. artykuły Znaczenie nazwy Polonia Maior, 1956; Uwagi o nazwach Pomorza Gdańskiego, 1956; Ogólne tendencje w rozwoju fleksji nazw geograficznych, 1958; O polskich nazwach miejscowych typu Stradom, Radzymin, 1958; Une tendance generale dans le développement de la flexion des noms de personnes, 1960; Polonais Kazimierz < Kazimier, gén. Kościuszki < Kościuszka et Piotrowicz < Piotrowic, 1961; A propos d'une nouvelle étymologie de Kiev, 1965; W sprawie nazwy Ustroń, 1965; O etymologii nazwy Ślaska, 1967; Développement de la déclinaison des noms propres en polonais, 1967; Le nom propre et le nom commun, 1968; Différence entre nom propre et nom commun, 1969; Pisownia nazw marek towarów, 1970; Pochodzenie nazw Białej, Czarnej i Czerwonej Rusi, 1975/2002; Etymologia nazwy Szczecin, 1975; W sprawie nazwy Stralsund, 1975; Typowe polskie nazwisko, 1976; La notion de nom propre, 1978/1982; Nazwy własne a rzeczowniki pospolite, 1986; Etymologia niemieckiego imienia Valeska, 1986; Jeszcze o niemieckim imieniu Valeska, 1991; La nature du nom propre. Prolégomènes, 1991; Geneza państwa polskiego a onomastyka, 1992; A propos de la double prononciation de Missouri, 1995; Onomastyka a ogólne prawidłowości językowe, 1998; O imieniu pierwszego władcy Polski, 1998; Etymologia nazw chorwackich typu Sutivan, 1998; W sprawie nazwiska Mudlaff, 1999; Nazwa słowiński, 2001; Najstarszy i największy problem onomastyki: istota nazw własnych, 2001; O tak zwanej hydronimii staroeuropejskiej, 2004; Praojczyzna Stowian a hydronimia, 2004; La nature des noms propres, 2005; W sprawie niem. Royn < pol. Ruja, 2006; Jeszcze o pisowni nazw marek towarów, 2006; Jeszcze o istocie nazw własnych, 2006; Rzekomo normańskie nazwisko Norwida, 2007; Jak się ma Gdynia do Gdańska, 2007; Pochodzenie nazwy Zakopane, 2007; Le prénom allemand Valeska, 2008; Czy cudzoziemcy nadali nazwę Polsce?, 2010; Etymologia nazwy Stambutu, 2010, Czy wszystkie chrematonimy sa nazwami wtasnymi, 2011, Etymologia nazwy Czajer, 2013). W swoich pracach sprawozdawczych i publikowanych recenzjach odnosił się również do zagadnień onomastycznych (zob. np. jego autorstwa A. Dauzat, Les noms de famille de France, 1958; S. Rospond, Klasyfikacja strukturalno-gramatyczna słowiańskich nazw geograficznych, 1961; J. Bubak, Nazwiska dawnego starostwa nowotarskiego, 1973; A. W. Supernaskaja, Obszczaja teoria imeni sobstwennogo, 1976; Polskie nazwy własne. Ency- 
klopedia, 1999; Z. Babik, Najstarsza warstwa nazewnicza na ziemiach polskich w granicach wczesnośredniowiecznej Stowiańszczyzny, 2002; E. Jakus-Borkowa, Polskie nazewnictwo kosmiczne, 2005).

Ostatnią pracą onomastyczną profesora Mańczaka jest zamieszczony w obecnym tomie artykuł na temat etymologii nazwy Polski. Profesor zlecił nam, jako redaktorom trzeciej części monografii w serii Nomina loci, dopracowanie jego rozważań. Wiemy, że dużo wiedzy onomastycznej będzie można pozyskać ze słownika etymologicznego języka polskiego, który profesor Mańczak ukończył tuż przed śmiercią, a manuskrypt skierował do prac wydawniczych.

Artur Gatkowski

Uniwersytet Łódzki

Artur Gatkowski

\section{Onomastic achievements of Professor Witold Mańczak (1924-2016)}

(Summary)

This memory of Professor Witold Mańczak deceased in 2016, presents the cv and the most important onomastic achievements of the outstanding and appreciated Polish linguist, who dedicated his scientific life to the study of different European languages and created some valuable theories concerning the evolution of languages, the etymology and the nature of proper names. 